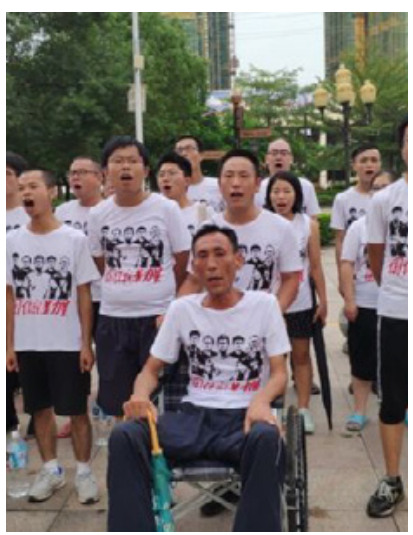

Jasic workers young and old. PC: Jasic Worker Solidarity

These arrests pose a puzzle. Why them? At the time of the crackdown, they were not part of any single labour organisation, nor were they active in the same city.

\section{State Repression in the Jasic Aftermath From Punishment to Preemption}

Kevin LIN

lthough several months have passed since the Jasic struggle (Zhang 2019), in the aftermath of the mobilisation labour activism remains under assault in China. On 20 January, five activists involved in various labour NGOs in Shenzhen were unexpectedly arrested (Elmer 2019). They were picked up by Shenzhen police in Shenzhen, Guangzhou, and Changsha. Among them, both $\mathrm{Wu}$ Guijun and Zhang Zhiru had established their own organisations to promote labour rights in the Pearl River Delta; Jian Hui had previously worked for Zhang's organisation but then split to establish his own group, which he was still heading at the time of his arrest; and He Yuancheng had worked for many years at a law firm known for its trainings of worker representatives and advocacy for collective bargaining (Hernández 2016; Elfstrom 2019). The last activist, Song Jiahui, had started as a worker representative and became a regular member of staff at Zhang's organisation, but had already left and relocated to Guangzhou long before her arrest.

These arrests pose a puzzle. Why them? At the time of the crackdown, they were not part of any single labour organisation, nor were they active in the same city. While three of them worked at different times for the same labour NGO, two had long left the organisation: one later set up his own group, while the other left labour activism entirely. Nor were they collaborating on any joint project or assisting workers in the same labour cases. Even before these arrests, because of the increased restrictions on labour NGO activities in the last couple of years, labour groups had already become considerably more cautious and supported far fewer labour disputes than before. No recent labour case, can be pinpointed to implicate any of them.

Are they connected to Jasic? As far as we can tell, none of them were participants in the Jasic case. In fact, at the height of the Jasic struggle in July 2018, the Jasic worker organisers and student supporters purposefully excluded labour NGOs from getting involved due to political differences and security concerns over linking up with this kind of organisations. As a result, labour NGOs decided to stay away, with the exception of the Migrant Workers Centre (打工者中心), an organisation based in Shenzhen. Fu Changguo, who worked for the Centre, 
The latest arrests invite comparison with the last major crackdown on labour NGOs in 2015, the first time that labour NGO activists were detained at such scale. There are many similarities. was arrested and remains detained to this day, allegedly due to his support for Jasic workers. However, he appears to have been minimally involved in the solidarity campaign, and is widely seen as having been scapegoated to provide substance to the allegations-raised by an editorial published by the Xinhua News Agency weeks after his arrest-that 'hostile forces' from Hong Kong were involved in the Jasic case (Xinhua 2018).

The latest arrests invite comparison with the last major crackdown on labour NGOs in 2015, the first time that labour NGO activists were detained at such scale. There are many similarities. First, the arrests of labour NGO activists on 3 December 2015 in Guangzhou were similarly highly coordinated, targeting multiple groups and rounding up dozens of NGO staff. Second, in both instances there was much confusion, and the reason for the arrests was not given until weeks later. In 2015 , those who were not released in the following weeks were charged and eventually put on trial for their role in support of worker mobilisation at the Lide footwear factory. This time, it also seems highly likely that the detained activists will be imprisoned. Finally, the breadth of the arrests in both 2015 and 2019 suggested that the target was a network, however loosely defined and connected, with broadly shared missions and goals centred around the idea of collective bargaining.

However, there is a key difference. The 2015 crackdown took place following a period of upturn in labour organising that began around 2010, in which labour NGOs played a role in amplifying the voices of striking workers. Prior to the crackdown, the Yue Yuan strike of over 40,000 workers in 2014 and the Lide strike of 2014-15 were landmark mobilisations that had impact beyond their locality. In the case of Lide, workers kept up their organising efforts over many months from late 2014 to early 2015, and led successful strike actions, rounds of bargaining, and even a factory occupation (Franceschini and Lin 2019). Workers secured their key demands of social insurance and layoff compensation, and the outcome boasted confidence in organising and in bargaining collectively. A Guangzhoubased labour NGO, Zeng Feiyang's Migrant Workers Centre (打工族), was involved in advising workers in bargaining, for which it became the main target of the crackdown in 2015. At that time, a small number of labour NGOs in both Shenzhen and Guangzhou were experimenting with supporting workers in bargaining in a time when collective bargaining was not only being taken up by workers, but also promoted by the AllChina Federation of Trade Unions (ACFTU) as a mechanism to resolve and preempt strikes. 
The 2019 crackdown, however, came at a different period. While the Jasic case attracted significant attention, it did not happen within the context of an upturn in labour organising comparable to the period prior to 2015.
The 2019 crackdown, however, came at a different period. While the Jasic case attracted significant attention, it did not happen within the context of an upturn in labour organising comparable to the period prior to 2015. Workers' organising in the past four years has been at a lower point, and labour NGOs have been much less active. It is possible that the arrest of the labour NGO activists in 2019 may be related to their past involvement in collective labour cases prior to 2015, when these individuals might have worked separately or together in promoting collective bargaining.

Thus, their arrest may be due to their potential, as people associated with the few remaining rights-based labour NGOs, to keep supporting workers in their struggle. If so, the arrests demonstrate an increasing sense of panic and crisis on the part of the Chinese Party-state, which anticipates the possibility of labour and other social unrest arising from the economic downturn, and decides to eliminate potential threats by arresting those who may assist workers' actions.

In late February 2019, one month after the arrest of the five activists, the public prosecutors charged them with 'gathering a crowd to disturb social order'-a catchall charge used regularly to target activists. There is little pretence of due process. The requests of family members and lawyers to meet with the arrested activists were repeatedly denied. Some of the families have even been pressured to withdraw their lawyers. This will not come as a surprise to anyone who has witnessed how activists have been treated in China in recent years. So, where does all this leave us?

First, as the repression widens, it is becoming increasingly arbitrary. Previously, if labour activists were harassed, questioned, or arrested, it was usually in relation to a recent and specific action they had taken part in. This did not mean that the boundaries of what was acceptable to the authorities were always clear-quite the opposite-but there was some clarity about the reasons for the repression. This time the authorities have not provided any explanation, nor are they even pretending to have a serious legal case against the arrested activists.

Second, the increasing arbitrariness in the widening repression is underlined by a decisive turn from punitive-where people are arrested as a response to their specific actions-to preemptive, where arrested activists may not be currently or recently engaged in any activism on a significant scale. Instead, the potential for their activism based on their past history is sufficient grounds for the Party-state to criminalise them. 
Across China today, very few of the remaining labour NGOs continue to engage in rights-based work. The very few that are still operating are now scattered, atomised, and starved of resources.
To be sure, repression is almost always a mix of punitive and preemptive measures, but of late we seem to be seeing a strong shift to the latter as a strategy to preempt activism. If this is the case, then we are likely to see more arrests of labour activists in the coming months.

Third, the implications of the latest repression are dire for labour and other rights-based NGOs. We may even be witnessing the end of 'labour NGOs' as an actor of change for the labour movement in China. While there has been debate about the extent to which they have been able to affect social change, it is impossible to dismiss their contribution entirely, as year after year they have been assisting workers with their legal cases on a daily basis, offering guidance to employees in collective negotiations, and transmitting experiences of labour organising (Franceschini and Lin 2019b). However, after the targeting of groups first in Guangzhou in 2015 and now Shenzhen in 2019, most of the active groups in the Pearl River Delta have ceased operation. In between, some others that were not targeted nevertheless closed their doors due to mounting pressure from the authorities.

Across China today, very few of the remaining labour NGOs continue to engage in rights-based work. Those that are still operating are now scattered, atomised, and starved of resources (Franceschini and Nesossi 2018). Others have, in the last couple of years, chosen to move away from rights-based work and have transformed themselves into social work and community organisations that may be more acceptable to authorities. Is this a viable route to survival for some groups? Perhaps, and some will make contributions in their new roles. But it is difficult to not see that the kind of rights-based activism of labour NGOs in China, which has existed for 20 years, is now at an end.

The disappearance of rights-based labour NGOs will not only deprive many workers of free or affordable legal assistance. More crucially, it will deprive the labour movement of its organisational basis, however limited it might be since these organisations are non-membership-based groups. It is even harder to envision what may emerge out of the ashes of the recent repression. However, repression alone cannot prevent workers from launching organised actions on their own. While the amplifying and solidarity-building role played by labour NGOs will be missing, workers will undoubtedly continue to organise autonomously. 